\title{
Evolution of “Chili” Tunisian landrace durum wheat sprouts properties after drying
}

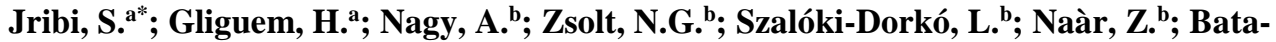

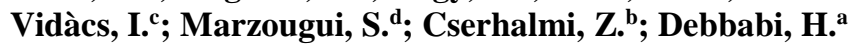 \\ ${ }^{a}$ National Institute of Agronomy of Tunisia (INAT), Research Unit UR17AGR01 "Innovation \& \\ Tradition”, University of Carthage, 43 Avenue Charles Nicolle, 1082 Tunis, Tunisia. \\ ${ }^{\mathrm{b}}$ Food Science Research Institute, National Agricultural Research and Innovation Centre, Herman \\ Otto utca 15, H-1022 Budapest, Hungary \\ c Agro-Environmental Research Institute, National Agricultural Research and Innovation Centre, \\ Herman Otto utca 15, H-1022 Budapest, Hungary \\ ${ }^{\mathrm{d}}$ National Institute of Cereal Crops (INGC), 8170 Bou Salem, Tunisia. \\ *E-mail of the corresponding author: Sarra.jribi@gmail.com
}

\begin{abstract}
Sprouting is a green technology contributing in improving cereals and pulses nutritional properties. However sprouts have a high water content limiting their shelf-life. This research focused on the impact of drying technology on physico-chemical, functional and nutritional properties of Tunisian landrace durum wheat (Triticum durum)“Chili” sprouts for their use as a functional ingredient. Three technologies were evaluated: lyophilisation, micro-wave vacuum drying and oven drying at $50^{\circ} \mathrm{C}$. Sprouted seeds flour properties were significantly $(p<0.05)$ affected by the drying methods used. Lyophilisation led to the highest preservation of bioactive compounds followed by micro-wave vacuum drying. The way of evolution of physico-chemical and functional properties depended on drying method used.
\end{abstract}

Keywords: Sprouts; drying; functional properties; bioactive compounds. 


\section{Introduction}

Consumers perception of eating has changed: food products are not only needed for satisfying hunger. They are also considered as a key factor in improving health and wellbeing [1]. To satisfy this need, food manufacturers are more and more interested in developing products with added nutritional value. Sprouting is an old practice used to enhance naturally seeds' nutrients and bioactive compounds [2]. Sprouting process increases also seeds moisture content. Thus sprouts couldn't have a long shelf life.

Drying is the simplest and the oldest method used for food preservation [3]. Several methods could be used to dry agricultural products, from home drying (oven, sun) to developed technologies. Depending on the used method, drying may lead to quality degradation [3]. Modifications affecting products' components (proteins, carbohydrates, lipids...) occurring during drying contribute in a modification of dried products functional properties [4]. For food manufacturers, these properties are an important parameter to take into account in food formulation. Particularly, for functional foods development, added to functional properties nutritional ones have a high interest.

The aim of this study is to evaluate the effect of different drying methods (convective hot air, lyophilisation and microwave vacuum drying) on physico-chemical, functional and nutritional properties of "Chili” Tunisian landrace durum wheat sprouts for its further use as a functional ingredient.

\section{Materials and Methods}

\subsection{Plant material}

"Chili” Tunisian cultivar of durum wheat (Triticum durum) was used in this study. It was introduced from France, and the pure line was registered in 1953 [5]. Samples (Harvested in 2015) were kindly provided by the National Gene Bank of Tunisia (BNG, Tunisia).

\subsection{In vitro sprouting}

Durum wheat seeds (Triticum durum) were germinated for $48 \mathrm{~h}$ after their disinfection with $1 \%(\mathrm{~V} / \mathrm{V})$ hypochlorite sodium solution.

\subsection{Drying}

Three drying methods were tested: convective hot air drying (L-MIM 320, Hungary) at $50^{\circ} \mathrm{C}$, lyophilisation (Christ freeze dryer alpha 1-4 LCS,Germany) after freezing at $-80^{\circ} \mathrm{C}$ and intermittent microwave vacuum drying (MVD) (60s on/off power at $850 \mathrm{Wand}$ a vaccum pressure of $1 \mathrm{kPa}$ ) using custom-designed MVD dryer. 
All drying experiments were performed in triplicate until reaching at least $15 \%$ water content. After drying, all samples were milled (Retsch Grindomix GM 200, Germany) and stored at $4^{\circ} \mathrm{C}$ until analysis.

\subsection{Physico-chemical properties}

Moisture content of all samples was analyzed using the AOAC oven method [6]. Novasina LabMaster $\mathrm{a}_{\mathrm{w}}$ (Switzerland) was used for water activity determination at $25^{\circ} \mathrm{C}$. Color was measured with a Konica Minolta Croma Meter CR 400 (Japan). The color parameters L*, a* and $\mathrm{b}^{*}$ were evaluated. Bulk density was determined according to the procedure previously described [7].

\subsection{Bioactive compounds}

Folin-Ciocalteu method was used for total phenol content assessement [8]. Total carotenoid pigments were determined [9]. DPPH (1,1-diphenyl-2-picrylhydrazyl) radical scavenging activity (DPPH RSA) was measured according to the suggested previously [8] with slight modification during extraction: Extraction was made with $80 \%(\mathrm{v} / \mathrm{v})$ aqueous methanol solution, for $2 \mathrm{~h}$ at $37^{\circ} \mathrm{C}$. Samples were afterwards centrifuged at 6,000 rpm for $30 \mathrm{~min}$. The supernatant was used for the determination of antioxidant capacity.

Antioxidant activity was calculated according to the following formula:

$\% D P P H ~ R S A=\left(1-A_{\text {Sample } / t=30 / A}\right.$ Control/t=0 $) * 100$

\subsection{Functional properties}

Water absorbance capacity (WAC) and Oil absorbance capacity (OAC) were determined [10]. Swelling power was evaluated following the described procedure [7].

\subsection{Statistical analysis}

Statistical analysis was carried out using the Minitab software (Minitab 17). All experiments were carried out in triplicate and the average values were reported together with standard deviations. Analysis of variance (ANOVA) was performed using the Fisher test. Significance was defined at $\mathrm{p}<0.05$.

\section{Results}

\subsection{Physico-chemical properties}

As shown in table 1, drying, regardless the method used, contributed to a significant decrease in water content and water activity. Results obtained show that shelf life may be extended as bacterial growth induced by sprouting could be stopped at the obtained levels of water activity. 
Drying induced changes in color parameters: a decrease in lightness was observed after oven and micro-wave vacuum drying unlike lyophilisation. For redness and yellow index, sprouted micro-wave vacuum dried samples showed a significant increase while a significant decrease was observed after oven drying and lyophilisation.

Table 1. Evolution of physico-chemical parameters of Chili's sprouted wheat flour $(n=3)$

\begin{tabular}{lllccc}
\hline Treatement & $\begin{array}{l}\text { Water } \\
\text { content (\%) }\end{array}$ & $\begin{array}{l}\text { Water } \\
\text { activity }(\mathbf{a} w)\end{array}$ & $\begin{array}{l}\text { Lightness } \\
\text { index }\left(\mathbf{L}^{*}\right)\end{array}$ & $\begin{array}{l}\text { Redness } \\
\text { index }\left(\mathbf{a}^{*}\right)\end{array}$ & $\begin{array}{l}\text { Yellow index } \\
\left(\mathbf{b}^{*}\right)\end{array}$ \\
\hline Raw & $10.13 \pm 0.07^{\mathrm{d}}$ & $0.488 \pm 0.00^{\mathrm{c}}$ & $74.99 \pm 0.06^{\mathrm{b}}$ & $2.87 \pm 0.02^{\mathrm{b}}$ & $18.94 \pm 0.03^{\mathrm{a}}$ \\
Sprouted & $59.81 \pm 0.09^{\mathrm{a}}$ & $0.991 \pm 0.00^{\mathrm{a}}$ & -- & -- & -- \\
Oven drying & $10.78 \pm 0.09^{\mathrm{c}}$ & $0.533 \pm 0.00^{\mathrm{b}}$ & $74.76 \pm 0.03^{\mathrm{b}}$ & $2.01 \pm 0.01^{\mathrm{c}}$ & $17.12 \pm 0.10^{\mathrm{b}}$ \\
$\begin{array}{l}\text { Lyophilisation } \\
\text { Micro-wave }\end{array}$ & $8.01 \pm 0.16^{\mathrm{e}}$ & $0.330 \pm 0.00^{\mathrm{e}}$ & $78.35 \pm 0.00^{\mathrm{a}}$ & $1.47 \pm 0.01^{\mathrm{d}}$ & $16.15 \pm 0.01^{\mathrm{c}}$ \\
vacuum drying & $13.83 \pm 0.04^{\mathrm{b}}$ & $0.478 \pm 0.00^{\mathrm{d}}$ & $67.48 \pm 0.40^{\mathrm{c}}$ & $3.68 \pm 0.08^{\mathrm{a}}$ & $19.34 \pm 0.40^{\mathrm{a}}$ \\
\hline
\end{tabular}

Means in same column that do not share same letters are significantly different, according to Fisher's test. --: Not determined

\subsection{Functional properties}

Results describing evolution of functional properties after sprouting and drying are summarized in table 2. Functional properties are a key factor in food conception. These properties are related to flour characteristics (composition, structure, cristallinity, polar groups...) [11]. Sprouting is a physiological event marked by degradation of macromolecules such as protein and starch $[12,13]$. As shown in table 2, functional properties of Chili's sprouted wheat flour were affected not only by sprouting, but also by the drying method: a significant decrease $(\mathrm{p}<0.05)$, depending on the drying method used, was observed in bulk density and swelling power as found previously [7]. The decrease in swelling power could be linked to the degradation of starch molecules during sprouting [14]. A decrease in water absorbance capacity was observed after drying except for micro-wave vacuum dried samples. For oil absorbance capacity, both sprouting and drying, the method used, induced a significant increase if compared to raw seeds. These findings are in agreement with a previous study dealing with sprouted cereals [15]. 
Authors : Jribi, S.; Gliguem, H. Nagy, A.; Zsolt, N.G.; Szalóki-Dorkó, L.; Naàr, Z.; Bata-Vidàcs, I.; Marzougui, S.; Cserhalmi, Z.; Debbabi, $H$.

Table 2. Evolution of functional properties of Chili's sprouted wheat flour after drying (n=3)

\begin{tabular}{lllll}
\hline Treatment & $\begin{array}{l}\text { Bulk density } \\
(\mathbf{g} / \mathbf{m l})\end{array}$ & $\begin{array}{l}\text { Water } \\
\text { absorbance } \\
\text { capacity } \\
\mathbf{( W A C ) ( g / g )}\end{array}$ & $\begin{array}{l}\text { Oil absorbance } \\
\text { capacity } \\
\mathbf{( O A C ) ( g / g )}\end{array}$ & $\begin{array}{l}\text { Swelling power } \\
\mathbf{( g / g )}\end{array}$ \\
\hline Raw & $0.77 \pm 0.01^{\mathrm{a}}$ & $0.92 \pm 0.00^{\mathrm{b}}$ & $1.02 \pm 0.00^{\mathrm{d}}$ & $6.11 \pm 0.05^{\mathrm{a}}$ \\
Oven drying & $0.74 \pm 0.00^{\mathrm{b}}$ & $0.90 \pm 0.01^{\mathrm{b}}$ & $1.05 \pm 0.02^{\mathrm{c}}$ & $3.74 \pm 0.08^{\mathrm{c}}$ \\
Lyophilisation & $0.74 \pm 0.00^{\mathrm{b}}$ & $0.84 \pm 0.00^{\mathrm{c}}$ & $1.28 \pm 0.01^{\mathrm{b}}$ & $3.71 \pm 0.05^{\mathrm{c}}$ \\
$\begin{array}{l}\text { Micro-wave } \\
\text { vacuum drying }\end{array}$ & $0.62 \pm 0.00^{\mathrm{c}}$ & $1.57 \pm 0.04^{\mathrm{a}}$ & $1.35 \pm 0.02^{\mathrm{a}}$ & $4.53 \pm 0.07^{\mathrm{b}}$ \\
\hline
\end{tabular}

Means in same column that do not share same letters are significantly different, according to Fisher's test.

\subsection{Nutritional properties}

Comparing raw seeds flours to sprouted freeze dried ones shows a significant increase in bioactive compounds $(+18.7 \%$ for carotenoids, $+118.7 \%$ for total phenol content) and consequently in antioxidant activity (+31.6\%). In fact, lyophilisation process is known by preserving products nutritional and sensory properties [16]. Our results about the role of sprouting in enhancing bioactive compounds are in agreement with previous studies [2]. Despite nutritional improvement induced by sprouting, micro-wave vacuum and convective drying decreased carotenoids and total phenol amounts significantly. Highest losses were obtained after oven drying, probably due to drying process duration if compared to microwave vacuum drying one.

Table 3. Effect of drying method on bioactive compounds and anti-oxydant activity of Chili's sprouted wheat flour

\begin{tabular}{llll}
\hline Treatment & $\begin{array}{l}\text { Carotenoids } \\
\text { carotene/kg dm) }\end{array}$ & $\begin{array}{l}\text { Total phenol content } \\
(\mathbf{m g ~ G A E} / \mathbf{g ~ d m})\end{array}$ & DPPH RSA \% \\
\hline Raw & $18.53 \pm 0.23^{\mathrm{b}}$ & $19.93 \pm 0.49^{\mathrm{b}}$ & $32.50 \pm 0.82^{\mathrm{b}}$ \\
Oven drying & $8.50 \pm 0.24^{\mathrm{c}}$ & $7.28 \pm 0.07^{\mathrm{d}}$ & $18.54 \pm 0.87^{\mathrm{d}}$ \\
Lyophilisation & $21.99 \pm 0.42^{\mathrm{a}}$ & $43.59 \pm 0.34^{\mathrm{a}}$ & $42.78 \pm 0.39^{\mathrm{a}}$ \\
$\begin{array}{l}\text { Micro-waves } \\
\text { drying }\end{array}$ & $18.06 \pm 0.18^{\mathrm{b}}$ & $13.00 \pm 0.06^{\mathrm{c}}$ & $24.99 \pm 0.45^{\mathrm{c}}$ \\
\hline
\end{tabular}

Means in same column that do not share same letters are significantly different, according to Fisher's test

GAE: Gallic Acid Equivalent, dm: dry matter bases, DPPH RSA: (1,1-diphenyl-2-picrylhydrazyl) radical scavenging activity 


\section{Conclusion}

Results of this study showed that drying amplified modifications induced by sprouting Chili's durum wheat seeds. All tested drying methods led to a decrease in moisture content and water activity which may increase sprouts shelf life and promote their use in cereal products. However, only lyophilisation allowed preservation of nutritional improvement obtained by sprouting. Evolution of functional properties depends on drying process adapted.

\section{References}

[1] Küster-Boluda, I ; Vidal-Capilla, I. Consumer attitudes in the election of functional foods. Spanish Journal of Marketing - ESIC 2017, 21, 65-79.

[2] Plaza, L.; De Ancos, B. ; Cano, M. P. Nutritional and health-related compounds in sprouts and seeds of soybean (Glycine max), wheat (Triticum aestivum.L) and alfalfa (Medicago sativa) treated by a new drying method. European Food Research and Technology 2003, 216, 138-144.

[3] Maskan M. Microwave/air and microwave finish drying of banana. Journal of Food Engineering 2000, 48, 71-78.

[4] Dehnad, D. ; Jafari, S.M. ; Afrasiabi, M. Influence of drying on functional properties of food biopolymers: From traditional to novel dehydration techniques. Trends in Food Science \& Technology 2016, 57, 116-131

[5 ] Ammar, K.; Gharbi, M. S. ; Deghaies M. Wheat in Tunisia. In Banjean, A. P., Angus W. J., Van Ginkel, M. The world wheat book: a history of wheat breeding Lavoisier, Londres-Paris-New York.2011.

[6] AOAC, 2000. Official Methods of Analysis, 17th ed. Association of Official Analytical Chemists.

[7] Singh, A.; Sharma, S.; Singh, B. Effect of germination time and temperature on the functionality and protein solubility of sorghum flour. Journal of Cereal Science 2017, 76, 131-139.

[8] Aprodu, L.; Banu, L. Antioxidant properties of wheat mill streams. Journal of Cereal Science 2012, 56, 189-195.

[9] Pasqualone, A.; Laddomada, B.; Centomani, I.; Paradiso, V. M.; Minervini, D.; Caponi, F.; Summo, C. Bread making aptitude of mixtures of re-milled semolina and selected durum wheat milling by-products. LWT - Food Science and Technology 2017, 78, 151159.

[10] Kaushal, P.; Kumar, V.; Sharma, H.K. Comparative study of physicochemical, functional, antinutritional and pasting properties of taro (Colocasia esculenta), rice 
(Oryza sativa) flour, pigeonpea (Cajanus cajan) flour and their blends. LWT - Food Science and Technology 2012, 48, 59-68.

[11] Gouw, V.P. ; Jung, J. ; Zhao, Y. Functional properties, bioactive compounds, and in vitro gastrointestinal digestion study of dried fruit pomace powders as functional food ingredients. LWT - Food Science and Technology 2017, 80, 136-144.

[12] Fardet, A. New hypotheses for the health-protective mechanisms of whole-grain cereals: what is beyond fibre? Nutrition Research Reviews 2010,23, 65-134.

[13] Koehler, P.; Hartmann, G.; Wieser, H.; Rychlik, M.Changes of Folates, Dietary Fiber, and Proteins in Wheat as affected by germination. Journal of Agriculture and Food Chemistry 2007, 55,4678-4683.

[14] Hung, P. V.; Maeda, T.; Yamamoto, S.; Morita, N. Effects of germination on nutritional composition of waxy wheat. Journal of the science of food and agriculture 2011,92,667672.

[15] Elkhalifa, A. E.; Bernhardt, R. Influence of grain germination on functional properties of sorghum flour. Food Chemistry 2010, 121, 387-392.

[16] Wojdyło, A.; Figiel, A.; Legua, P.; Lech, K.; Carbonell-Barrachina, A.A.; Hernández, V. Chemical composition, antioxidant capacity, and sensory quality of dried jujube fruits as affected by cultivar and drying method. Food Chemistry 2016, 207, 170-179. 